\title{
PACHYSTELA BREVIPES (BAK.) ENGL (SAPOTACEAE) STERM BARK DECOCTION EXHIBITED ESTROGENIC EFFECTS IN OVARIECTOMIZED WISTAR RAT
}

\author{
Zemo Gamo Franklin \\ Department of Animal Biology and Physiology, \\ Faculty of Science \\ Department of Psychology, \\ Faculty of Arts, Letters and Social Science \\ University of Yaounde I, Yaounde, Cameroon

\section{Ketcha Wanda Germain Jean Magloire \\ Department of Psychology,} \\ Faculty of Arts, Letters and Social Science. \\ University of Yaounde I, Yaounde, Cameroon
}

\author{
Ateba Sylvin Benjamin \\ Department of Biological Science, \\ Faculty of Science \\ University of Douala, Douala, Cameroon.
}

\author{
Djiogue Sefirin \\ Department of Animal Biology and Physiology, \\ Faculty of Science. \\ University of Yaounde I, Yaounde, Cameroon
}

\section{Njamen Dieudonne \\ Department of Animal Biology and Physiology \\ Faculty of Science. \\ University of Yaounde I, Yaounde, Cameroon}

\begin{abstract}
Pachystela brevipes (Bak.) Engl (Sapotaceae) is a plant used in West region of Cameroon to improve conception and alleviate vaginal dryness in elderly women. Thus, this study was designed to evaluate the potential estrogenic of the decoction of stem bark of $P$. brevipes $(175$, 350 and $700 \mathrm{mg} / \mathrm{kg} \mathrm{BW}$ ) using a 3-day uterotrophic assay in ovariectomized rats. $P$. brevipes extract had no effect uterine wet weight while, significantly $(p<0.05)$ increased uterine (at 350 and $700 \mathrm{mg} / \mathrm{kg}$ ) and vaginal (at $700 \mathrm{mg} / \mathrm{kg}$ ) epithelial thickness. Moreover, this extract induced an E2V-like effect on mammary gland by increased the diameter of alveoli and induced eosinophil secretion at all tested doses. These results suggest that $P$. brevipes extract is endowed with estrogenic properties and could justify its traditional used.
\end{abstract}

Keywords- Pachystela brevipes, estrogenic properties, ovariectomized Wistar rat, stem bark

\section{INTRODUCTION}

Pachystela brevipes (Bak.) Engl (syn. Synsepalum brevipes (Baker) T. D. Penn), commonly known as star apple of the forest, belongs to the Sapotaceae family. This evergreen tree is widely distributed in West and Central Africa (from Senegal to Cameroon), Sudan, East Africa and Mozambique [1,2]. It is also found in the Middle East and South Asia [1]. Throughout these African Regions, this indigenous fruit tree is known for its potential in nutritional values, environmental stability, and economic development $[3,4]$. The hard, heavy and durable wood is used for pestles, tool handles, stakes, seats, canoes, domestic utensils, and for fuel and making charcoal [5]. The fruit containing a milky juice and white mucilaginous acid-sweet pulp is edible, very frequently as a snack. In Uganda its consumption has been reported in people living with HIV/AIDS because of their presumed nutrition and health benefits [6]. In traditional medicine, the fruit pulp is used against jaundice and nausea while, the latex from this fruit is applied as a galactagogue [5]. On the other hand, a root decoction is taken to treat malaria and as an aphrodisiac while, root sap and bark is drunk to treat coughs, colds, hernia and stomach complaints [5]. Others uses of this plant include hookworm infection of the small intestine, malaria, pneumonia, oedema, swellings, stomach complaints and toothaches [7,8,9]. In the West Region of Cameroon (Mamougnam, Noun Division) this plant is also used for conception and to alleviate vaginal dryness in postmenopausal women. In previous studies, antibacterial [2], antidiabatic, antifecdant and contraceptive effects $[10,11,12,13,14]$ have been reported. On the other hand, the phytochemical analysis of $P$. brevipes showed the presence of carbohydrates, cardiac 


\section{International Journal of Engineering Applied Sciences and Technology, 2020 \\ Vol. 4, Issue 11, ISSN No. 2455-2143, Pages 67-72 \\ Published Online March 2020 in IJEAST (http://www.ijeast.com)}

glycosides, saponins, steroids, triterpenes, flavonoids, tannins and alkaloids [2]. Based on these information, mainly the traditional uses of this plant as galactagogue and against vaginal dryness, we hypothetized that this plant could exhibit estrogenic effects. Therefore, the present study was designed to evaluate the estrogenic properties of the decoction of stem bark of Pachystela brevipes using a 3-day uterotrophic assay in ovariectomized adult rats, an excellent and recommended tool for the screening of estrogenic properties of extracts and compounds [15]. The investigation in this assay focus on the estrogen primary targets for including uterus (wet weight and epithelial height), vagina (epithelial height) and mammary gland features.

\section{MATERIAL AND METHODS}

\section{II.1. Animals}

Juvenile female Wistar rats weighed $130 \pm 3 \mathrm{~g}$ and aged 10-12 weeks were used. They were obtained from the breeding facility of the Animal Physiology Laboratory, University of Yaounde 1, and housed in in clean plastic cages at room temperature (around $25^{\circ} \mathrm{C}$ ) under natural illumination (approx. $12 \mathrm{~h}$ light/dark). Animals had free access to tap water and soyfree rat chow ad libitum. Animal handling and experiments were carried out in conformity with the European Union on Animal Care (CEE Council 86/609) guidelines adopted by the Institutional Ethics Committee of the Cameroon Ministry of Scientific Research and Technology Innovation.

\section{II.2. Plant material}

Stem barks of Pachystela brevipes were collected in Mamougnam (Noun Division, West Region of Cameroun). This botanical sample was authenticated at the National Herbarium of Cameroon (HNC) in comparison to the specimens deposited under the voucher number 3851/SRKF/HNC.

\section{II.3. Plant extraction and determination of doses}

The aqueous extract of Pachystela brevipes was prepared following the traditional instructions. $683 \mathrm{~g}$ of air-dried and carved stem bark were carried to ebullition for $45 \mathrm{~min}$ in $2 \mathrm{~L}$ of water. After cooling and filtration using Wattman filter paper $\mathrm{n}^{\circ} 4$, the solution was lyophilized and $6.7 \mathrm{~g}(0.98 \%)$ of the dried extract obtained. The extract was kept at $4^{\circ} \mathrm{C}$ until use.

The doses of administration were obtained based on the traditional dosage in human $(\sim 56 \mathrm{mg} / \mathrm{kg} /$ day $)$. The equivalent dose in rat of $350 \mathrm{mg} / \mathrm{kg} \mathrm{BW}$ was obtained using allometric calculations [16]. Using the factors of $1 / 2$ and 2 , the doses of 175 and $700 \mathrm{mg} / \mathrm{kg}$ were also obtained and used in this study.

\section{II.4. Experimental design}

Twenty-five female Wistar rats were ovariectomized under diazepam and ketamine anesthesia $(10 \mathrm{mg} / \mathrm{kg} \mathrm{BW}$ and 50 $\mathrm{mg} / \mathrm{kg}$ BW i.p., respectively). Fourteen days after ovariectomy, the rats were randomly distributed into five groups of five rats each. OVX group received vehicle (distilled water), the second group (positive control) received $1 \mathrm{mg} / \mathrm{kg} \mathrm{BW}$ of estradiol valerate $\left(\mathrm{E}_{2} \mathrm{~V}\right)$ and the three remaining groups received the extract of stem bark of $P$. brevipes at the doses of 175,350 and $700 \mathrm{mg} / \mathrm{kg} \mathrm{BW}$, respectively. Animals were orally (gavage) and once daily treated $(2 \mathrm{ml} / 100 \mathrm{~g})$ for 3 days between 9 to 11 a.m. Twentyfour hours after the last administration, animals were sacrificed under diazepam and ketamine anesthesia. Uterus, vagina and mammary gland were removed. Prior to the fixation of these organs in $10 \%$ formaldehyde solution for histological analysis, uterine wet weight was determined.

\section{II.5. Histological analysis}

Histological analyses of mammary glands, uterus and vagina were assessed from $5-\mu \mathrm{m}$ sections of paraffin-embedded tissues. Following hematoxylin-eosin staining, the uterine and vaginal epithelial heights as well as mammary alveolar gland and ductal features were assessed on microphotographs using the complete Zeiss equipment consisting of a microscope Axioskop 40 connected to a computer where the image was transferred with the MRGrab1.0 and AxioVision 3.1 software, all provided by Zeiss (Hallbermoos, Germany).

\section{II.6. Statistical analysis}

Data were expressed as the mean \pm S.E.M and analyzed using GraphPad Prism 5.03 software. One-way analysis of variance (ANOVA) followed by Dunnett's test was used. Differences were considered significant for $\mathrm{p}<0.05$.

\section{RESUlTS}

\section{III.1. Effects of $P$. brevipes extract on uterus}

Compared to OVX group, the 3-day treatment of ovariectomized animals with the reference substance estradiol valerate $(1 \mathrm{mg} / \mathrm{kg})$ induced a 5- and 3.5-fold increase $(\mathrm{p}<$ 0.001) of uterine wet weight (figure 1A) and epithelial height (Figure 1B). The decoction of stem bark of $P$. brevipes did not induced affected the uterine wet weight while, increased $(\mathrm{p}<$ 0.05) the uterine epithelial height at the doses of 350 and 700 $\mathrm{mg} / \mathrm{kg} \mathrm{BW}$ (figure $1 \mathrm{~B}$ and figure 1C). Compared to OVX control animals in which epithelium is cubic, the photomicrographs of uterus of animals treated with the $P$. brevipes extract at the doses of 350 and $700 \mathrm{mg} / \mathrm{kg}$ showed a tall cuboidal epithelium (Figure 1C). 


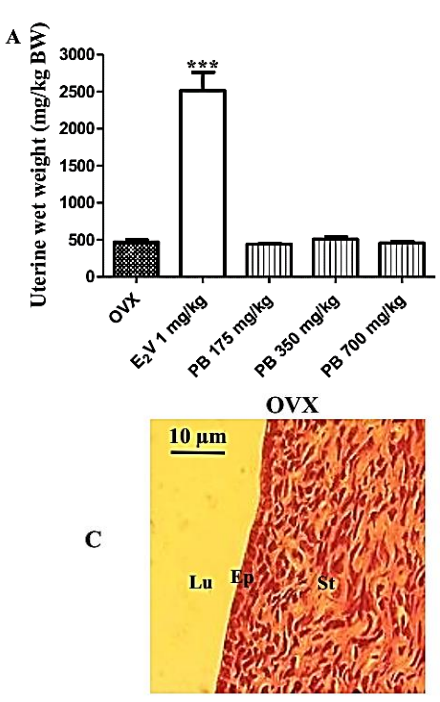

B
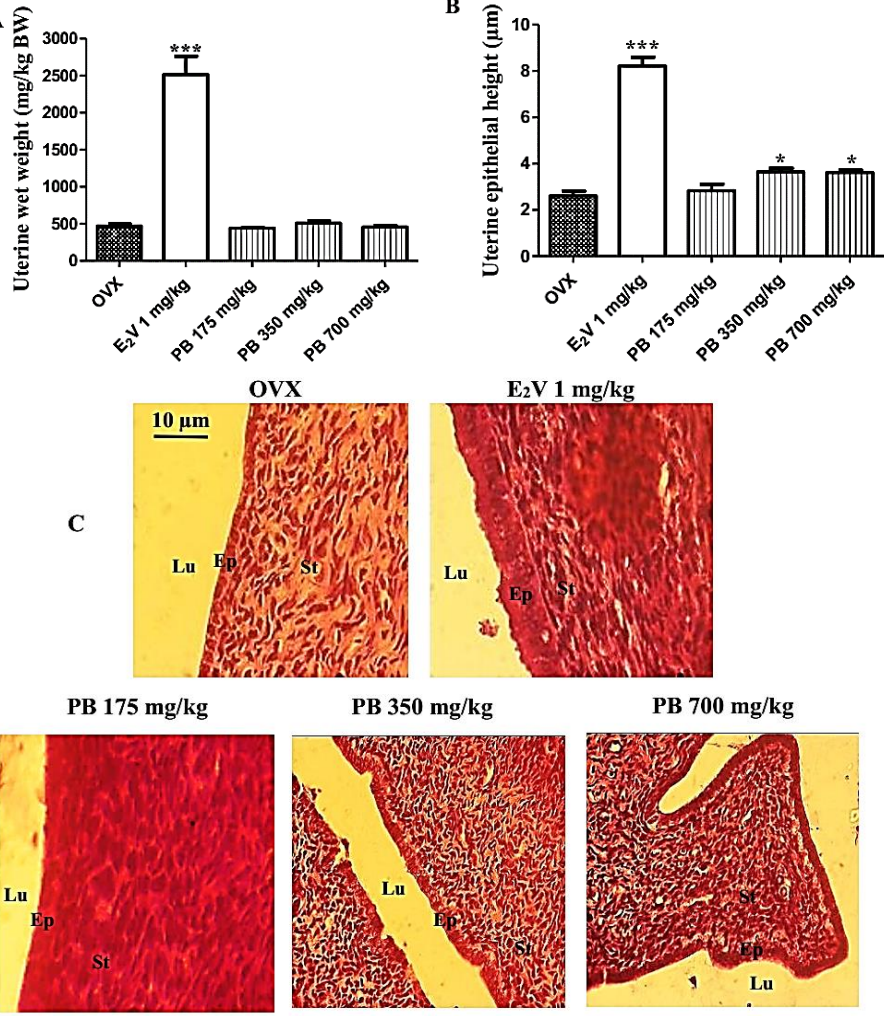

PB $350 \mathrm{mg} / \mathrm{kg}$
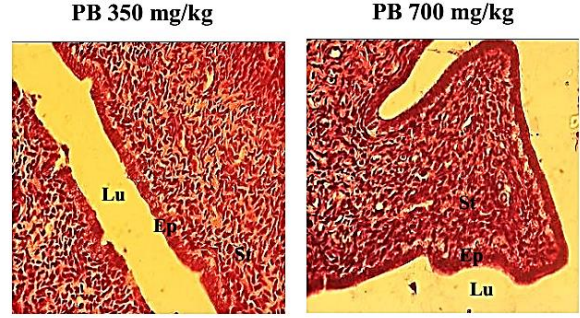

Figure 1: Effects of Pachystela brevipes extract on the uterine wet weight (A) and epithelial thickness (B and C).

$\mathrm{OVX}=$ ovariectomised animals treated with the vehicle, $\mathrm{E}_{2} \mathrm{~V}$ $=$ ovariectomised animals treated with estradiol valerate at 1 $\mathrm{mg} / \mathrm{kg} \mathrm{BW}, \mathrm{PB}=$ ovariectomised animals treated with the decoction of $P$. brevipes at the doses of 175,350 and 700 $\mathrm{mg} / \mathrm{kg} \mathrm{BW} .{ }^{* *} \mathrm{p}<0.05,{ }^{* *} \mathrm{p}<0.01$ vs. OVX. Lu: lumen; Ep: Uterine epithelial ; St: Stroma.

\section{III.2. Effects of Pachystela bevipes extract on vagina}

As shown in figure 2, the 3-day treatment with the aqueous extract of the stem bark of $P$. brevipes at the dose of 700 $\mathrm{mg} / \mathrm{kg} \mathrm{BW}$ as well as estradiol valerate, induced a significant $(p<0.001)$ increase of the vaginal epithelial height (Figure 2 A and B) as compared to OVX group. However, the increase of that parameter in rats treated with P. brevipes is 3.7-fold lower than that induced by $\mathrm{E}_{2} \mathrm{~V}$. Vaginal epithelium of OVX animals only consisted of a thin layer of cubic cells, the stratum germinativum while, stratum germinativum and stratum granulosum were present in groups treated with $P$. brevipes at the doses of $700 \mathrm{mg} / \mathrm{kg}$ (Figure $2 \mathrm{~B}$ ).

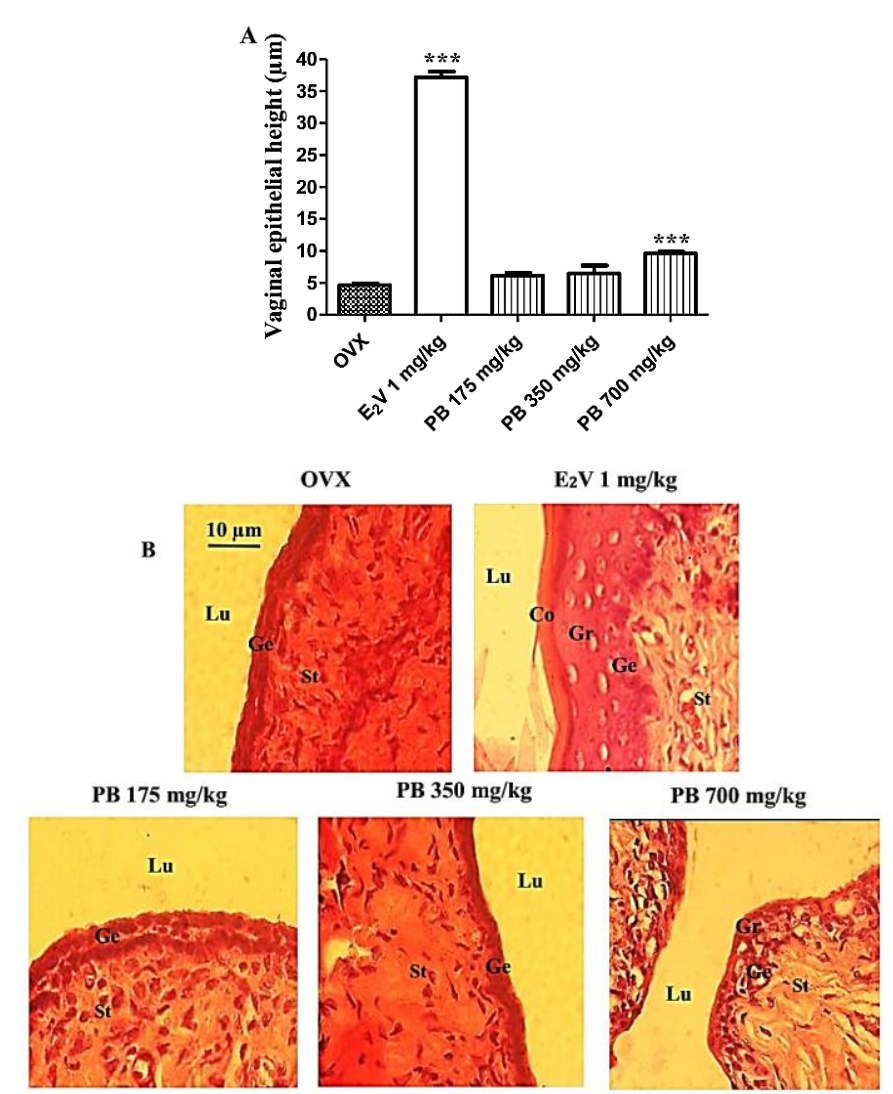

Figure 2: Effects of Pachystela brevipes extract on the vaginal epithelial thickness.

$\mathrm{OVX}=$ ovariectomised animals treated with the vehicle, $\mathrm{E}_{2} \mathrm{~V}$ $=$ ovariectomized animals treated with estradiol valerate at 1 $\mathrm{mg} / \mathrm{kg} \mathrm{BW}, \mathrm{PB}=$ ovariectomized animals treated with the aqueous extract of $P$. brevipes at the doses of 175,350 and $700 \mathrm{mg} / \mathrm{kg} \mathrm{BW}$. ***p < 0.001 vs. OVX. Lu lumen, Co $=$ stratum corneum, Gr =stratum granulosum, Ge = stratum germinativum, $\mathrm{St}=$ stroma.

\section{III.3. Effects of Pachystela brevipes extract on mammary gland \\ Microphotograph analysis shows that compared to OVX group, treatment with $\mathrm{E}_{2} \mathrm{~V}(1 \mathrm{mg} / \mathrm{kg} \mathrm{BW})$ increased the diameter and the lumen of alveoli, and displayed abundant eosinophil secretion (Se) in the lumen of alveoli (Figure 3) indicating a proliferative activity. The 3-day treatment with the decoction of Pachystela brevipes induced a similar effect. Compared to OVX group, increased diameter of alveoli and eosinophil secretion were observed at all tested doses.}



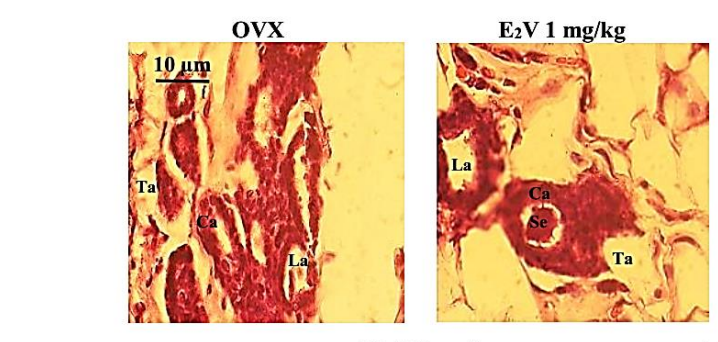

PB $175 \mathrm{mg} / \mathrm{kg}$
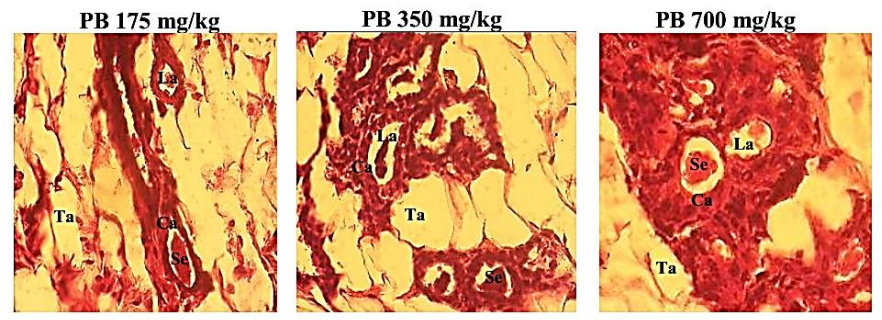

Figure 3: Effects of Pachystela brevipes extract on mammary gland.

$\mathrm{OVX}=$ ovariectomised animals treated with the vehicle, $\mathrm{E}_{2} \mathrm{~V}$ $=$ ovariectomized animals treated with estradiol valerate at 1 $\mathrm{mg} / \mathrm{kg} \mathrm{BW}, \mathrm{PB}=$ ovariectomized animals treated with the aqueous extract of $P$. brevipes at the doses of 175,350 and $700 \mathrm{mg} / \mathrm{kg}$. La = lumen of alveoli, Ep = aveoli epithelium, At $=$ adiposite tissue, $\mathrm{Se}=$ eosinophil secretion.

\section{DISCUSSION}

Estrogen deficiency is associated with numerous problems affecting women's health and well-being such as urogenital atrophy and vaginal dryness [17], osteoporosis, cardiovascular diseases [18], depression, anxiety, loss of cognition [19,20], oxidative activity and many neurodegenerative processes $[21,22]$. To face these unwanted effects, hormone replacement therapy (HRT) has been used for decades [23,24]. However, its long-term usage is associated with serious side effects such as the increased risk of endometrial and breast cancers [24]. For this raison, many women refuse or discontinue treatment. In this context, alternatives are needed and plants, used by $80 \%$ of the population in developing countries [25], are being considered [26,27].

In this study, compared to OVX group, the decoction of the stem bark of $P$. brevipes extract did not modified the uterine wet weight, but it induced a significant increase of the uterine epithelial thickness at the dose of 350 and $700 \mathrm{mg} / \mathrm{kg} \mathrm{BW}$. The uterine growth is a biphasic phenomenon including hyperemia and water imbibition in the early phase and epithelial cell proliferation and differentiation as late responses [28]. In vagina, the 3-day treatment with $P$. brevipes induced a significant increase of the epithelial height at the dose $700 \mathrm{mg} / \mathrm{kg}$ BW. By contrast to the non-treated ovariectomized animals (OVX) in which vaginal epithelium only consisted of a thin layer of cubic cells, stratums germinativum and granulosum were observed in animals receiving the $P$. brevipes extract indicating the proliferation and stratification of the epithelium. Such result on the vagina suggests that $P$. brevipes could prevent vaginal dryness. Both uterine growth and vaginal proliferation and differentiation are known to be mediated by the ER $\alpha$ receptor. Although not tested on estrogen receptors, the proliferative effects of $P$. brevipes observed in uterus and vagina appear to be mediated, at least in part, by the ER $\alpha$.

Mammary glands generally exhibit a pattern of ductal branching and alveolar budding in response to estrogen and estrogenic substances [29]. In this study, the decoction of the stem bark of $P$. brevipes, at all tested doses, induced $\mathrm{E}_{2} \mathrm{~V}$-like effects on mammary gland by increasing the diameter and the lumen of alveoli, and displaying an abundant eosinophil secretion in lumen of alveoli. Such results have been previously observed by authors [30,31,32], who reported that estrogen-like substances (phytoestrogens) can reverse mammary gland regression induced by ovariectomy.

It is well known that the growth of the female reproductive tract is a hallmark of estrogen activity [30,31]. Therefore, the estrogenic properties observed in estrogen-deficient animals following administration of $P$. brevipes extract could be ascribed to plant mimic estrogen so-called phytoestrogens. Phytoestrogens are well known to belong to several chemical classes identified in this plant such steroids, triterpenes and flavonoids.

\section{CONCLUSION}

The aim of this study was to evaluate the estrogenic effects of Pachystela brevipes on the some estrogen primary targets, using a 3-day uterotrophic assay in ovariectomised rats. Our results showed that the decoction of stem bark of $P$. brevipes induced a significant estrogen-like activity on uterine, vagina and mammary gland. These results suggest that this extract is endowed with estrogenic properties and could justify it traditional used to alleviate vaginal dryness in postmenopausal women.

\section{ACKNOWLEDGMENT}

The authors are thankful to Guemnang Ngitedem Steve and Awounfack Charline Florence, Department of Animal Biology and Physiology, Faculty of Science, University of Yaounde I, for technical assistance.

\section{REFERENCES}

[1] Hall J.B., and Walker D.H. (1991). Pachystela brevipes Del. A monograph school of Agricultural and Forest Science, University of Wales, 1-60 Bangor.

[2] Ezuruike I.T., Aba O.Y., Habila J.D., and Ndukwe G.I. (2015). Isolation, characterization and antibacterial evaluation of Zymosterol from the Root of Pachystela Brevipes (Sapotaceae), in Scholars Academic Journal of Pharmacy, (pp. $35-41$ ).

[3] Okia C.A. (2007). Balanites Kernels for oil extraction in adjumania district. U.S. Department of Agriculture. http://wwww.ars.USdagov/service (April). 


\section{International Journal of Engineering Applied Sciences and Technology, 2020 \\ Vol. 4, Issue 11, ISSN No. 2455-2143, Pages 67-72 \\ Published Online March 2020 in IJEAST (http://www.ijeast.com)}

[4] Ezigbo V.O., Oluigbo I.C., Onukwube S.I., and Nwajiobi C.C. (2016). Physico-Chemical Properties of Pachystela brevipes Seed Oil from Anambra State Southeastern Nigeria, in International Journal of Engineering Research \& Technology, (pp. $151-153)$.

[5] Lemmens R.H.M.J. (2007). Synsepalum brevipes (Baker) T.D.Penn. In: Louppe, D., Oteng-Amoako, A.A. \& Brink, M. (Editors). PROTA (Plant Resources of Tropical Africa / Ressources végétales de l'Afrique tropicale), Wageningen, Netherlands. https://uses.plantnetproject.org/fr/Synsepalum_brevipes_(PROTA), accessed on February 22, 2020.

[6] Nabatanzi, A. and Nakalembe, I. (2016). Wild food plants used by people living with HIV/AIDS in Nakisunga subcounty, Uganda. African Journal of Food, Agriculture, Nutrition and Development, 16: 11310-11330.

[7] Shariff Z.U. (2001). Chemical composition and antimicrobial activity of the essential oils from the gum of Turkish pistachio (Pistacia vera L.), in Journal of Agricultural and Food Chemistry, (pp.3911 - 3914).

[8] De N., and Ifeoma E. (2002). Antimicrobial effects of components of the bark extracts of Neem (Azadirachta A. Juss), in Technology and Development, (pp. 23 - 28).

[9] Liu M.J., Wang Z., Ju Y., Wong R.N., and Wu Q.Y. (2005). Diosgenin induces cell cycle arrest and apoptosis in human leukemia K562 cell with the disruption of $\mathrm{Ca} 2+$ homeostasis, in Cancer chemotherapy and Pharnacology, (pp. $79-90)$.

[10] Jain D.C., and Tripathi A.K. (1991). Inseet Feeding Different activity of saponin glycosides, in Phytotherapy Research, (pp. 139 - 141).

[11] Kamel M.S., Kanel M.S., Obtani K., Kurokawa T., Assat T., El-Shanawany M.H., and Ali M.A. (1991). A Furostanol Saponin from fruits of Balanites aegyptiaca, in Phytochemistry, (pp. 755 - 757).

[12] Liu H.W., and Nakanishi K. (1982). The structures of Balanitins potent mollucides isolate from Balanite aegyptiaca, in Tetrahedron, (pp. $513-519$ ).

[13] Ibrahnim A.M. (1992). Anthelmintic activity of some Sudanese medicinal plants, in Phytotherapy Research, (pp. $155-157$ ).

[14] Rao M.V.K.D., Shah M., and Rajani (1997). Contraceptive efficacy of balanite roxburghii pericarp extract in male mice (Miisimisciilus), in Phytotherapy Research, pp. 469 - 471).

[15] OECD, Organisation for Economic Co-operation and Development (2007). Third meeting of the validation management group for the screening and testing of endocrine disrupters (mammalian effects). Joint meeting of the chemicals committee and the working party on chemical, pesticides and biotechnology. http://www.oecd.org, 2007.

[16] FDA, Food and Drug Administration (2005). Guidance for industry: Estimating the maximum safe starting dose in initial clinical trials for therapeutics in adult healthy volunteers. Center for Drug Evaluation and Research (CDER) at the U.S. Dept. of Health \& Human Services: Rockville, USA. From: http://www.fda.gov/cder/guidance/index.htm.

[17] Versi E., Harvey M.A., Cardozo L., Brincat M., and Studd J.W.W. (2001). Urogenital prolapse and atrophy at menopause. A prevalence study, in International Urogynecology Journal, (pp. 107 - 110).

[18] Muniyappa R., and Tella S.H. (2018). Osteoporosis and Cardiovascular Disease in the Elderly. Conn's Handbook of Models for Human Aging. Second edition. ISBN: 9780-12-811353-0. http://doi.org/10.1016/C2016-0-00505-3.

[19] McEwen B.S. (2001). Invited Review: Estrogens effects on the brain: multiple sites and molecular mechanisms, in Journal of Applied Physiology, (pp. 2785 - 2801).

[20] Walf A.A., and Frye C.A. (2007). The use of the elevated plus maze as an assay of anxiety-related behavior in rodents, in Nature Protocols, (pp. 322 - 328).

[21] Honjo H., Kikuchi N., Hosoda T., Kariva K., Kinoshita Y., Iwasa K., Ohkubo T., Tanaka K., Tamura T., Urabe M., and Kawata M., (2001). Alzheimer's disease and estrogen, in Journal of Steroid Biochemistry and Molecular Biology, (pp. 227 - 230).

[22] Sanchez-Rodriguez M.A., Zacarias-Flores M., ArronteRosales A., Correa-Munoz E., and Mendoza-Nunez V.M. (2012). Menopause as risk factor for oxidative stress, in Menopause, (pp. $361-367$ ).

[23] Umland E.M., Cauffield J.S., Kirk J.K., and Thomason T.E. (2000). Phytoestrogens as therapeutic alternatives to traditional hormone replacement in postmenopausal women, in Pharmacotherapy, (pp. 981 - 990).

[24] Burger H. (2003). Hormone replacement therapy in the post-Women's Health Initiative era. Report of a meeting held in Funchal, Madeira, February 24-25, 2003, in Climacteric, (pp. 11 - 36).

[25] WHO, World Health Organization (2008). Traditional medicine. Fact sheet 134. 2003-05. Archived from the original : 07-28.

[26] Low Dog T. (2005). Menopause: a review of botanical dietary supplements, in The American Journal of Medicine, (pp. 98 - 108).

[27] Scheid V. (2007). Traditional Chinese medicine -what are we investigating? The case of menopause, in Complementary Therapies in Medicine, (pp. 54 - 68).

[28] Hewitt S.C., Deroo B.J., Hansen K., Collins J., Grissom S., Afshari C.A., and Korach K.S. (2003). Estrogen receptor-dependent genomic responses in the uterus mirror the biphasic physiological response to estrogen, in Molecular Endocrinology, (pp. 2070 - 2083).

[29] Santell R.C., Chang Y.C., Nair M.G., and Helferich W.G. (1997). Dietary genistein exerts estrogenic effects upon the uterus, mammary gland and the hypothalamic/pituitary axis in rats, in Journal of Nutritrition, (pp. 263 -269). 
[30] Zingue S., Njamen D., Tchoumtchoua J., Halabalaki M., Simpson E., Clyne C., and Magne Nde C.B. (2013). Effects of Millettia macrophylla (Fabaceae) extracts on estrogen target organs of female Wistar rat, in Journal of Pharmacological Sciences, (pp. 120 - 131).

[31] Njamen D., Djiogue S., Zingue S., Mvondo M.A., and Nkeh-Chungag B.N. (2013). In vivo and in vitro estrogenic activity of extracts from Erythrina poeppigiana (Fabaceae), in Journal of Complementary and Integrative Medicine, (pp. 1 - 11).

[32] Ketcha W.G.J.M., Zemo G.F., Djiogue S., Awounfack C.F., and Njamen, D. (2017). Estrogenic and anxiolytic effects of the decoction of stem bark of Khaya anthotheca (Welw.) C.DC (Meliaceae) in ovariectomised Wistar rats, in International Journal of Phytomedicine, (pp. 241-252). 